\title{
BUDDHISM IN MODERN INDIA: ASSERTION OF IDENTITY AND AUTHORITY FOR DALITS (SOCIAL CHANGES AND CULTURAL HISTORY)
}

\author{
Dr. Preeti Oza \\ Department of English \\ St. Andrew's College \\ University of Mumbai \\ preetioza1@gmail.com
}

\begin{abstract}
In the Lotus Sutra (the first Sutra introduced into China and Vietnam from India), the Buddha is described as the most respected and loved creature who walked on two feet. This was precisely the reason why Dalits in India have started the Navayana Buddhism or the Neo- Buddhist movement which is a very socially and politically engaged form of Buddhism. For Dalits, whose material circumstances were very different from the mainstream upper castes, the motivation always remained: to learn about suffering and to reach its end, in each person's life and in society. Many of them have turned to Dhamma in response to the Buddha's central message about suffering and the end of suffering.

Previously lower-caste Hindus, the Indian Buddhists in Nagpur converted under the political influence of Babasaheb Ambedkar, the author of India's constitution, to denounce caste oppression. They became Buddhist for political and spiritual reasons, and today, the implications of their actions continue to unfold in many ways. Their belief in the four seals of Buddhism - All compounded things are impermanent, All emotions are the pain, All things have no inherent existence and Nirvana is beyond concepts, have made them renounce the atrocities and injustice of Hindu savarnas which were carried on since last many centuries.

It is well known that Buddha began his investigation into the mysteries of life by his acute awareness of the painful aspects of his immediate experiences. His encounter with the disease, old age, death, and its sorrowful effects were instrumental in developing a whole philosophy based on the fact of suffering (duhkha).In his book The Buddha and His Dhamma, Dr. Ambedkar has proposed his concept of Navaya Buddhism which was not very similar to the mainstream traditional Buddhism. His idea was more to discard the practices of karma, rebirth in an afterlife, or related rituals and to use religion in terms of class struggle and social equality. He adopts science, activism, and social reform as a form of Engaged Buddhism. Many critics have identified this phenomenon as a synthesis of the ideas of modern Karl Marx into the structure of ideas by the ancient Buddha.

-Whenever the ethical or moral value of activities or conditions is questioned, the value of religion is involved; and all deep-stirring experiences invariably compel a reconsideration of the most fundamental ideas, whether they are explicitly religious or not.\| (Encyclopaedia of Religion and Ethics). This paper tries to discuss the role of Buddhism in Modern Indian social problematic reference to context.
\end{abstract}

\section{SOCIAL EMANCIPATORY MOVEMENTS AND LITERATURE}

Dalit literature is a literature of revolt and enigma, protest, and negativism. The social, economic and cultural inequality faced by _Untouchables' finally made them start and join many movements. The protest against the establishment of the Dalits gained the very first expression amidst the Dalit literature. In the midst of the cobweb of poems, fiction, novels, and autobiographies the age-old questions of Dalit identity were addressed. These movements have a long history and which also is spreads into many verticals of parallel protests. The Dalit literary movement in India is significant not only from the literary perspective but it has changed the whole spectrum of socio-political writings in many parts of India. It has provided a new avenue of liberation for Dalits.

The caste system, =Verna =system, untouchability, and social discrimination have subjugated a very large part of our society. Dr. Ambedkar named it _Dalit' and Indian Constitution called it _Scheduled Caste', but this marginalized group has existed consistently in our history of time. Shudra, Atishudra, Pancham, Avarna, Ashprushya, Chandal, Antyaj, Dhedh, Bhangi, Harijan, Dalit, Depressed class, Bahujan... are some of the identities given to them with little pride and more of insult. So the need of any literature or journalism which gives voice to these people is very clear.

\section{THE BEGINNING}

Dalit literary movement began in Maharashtra, the birthplace of Dr. Babasaheb Ambedkar. Many small-scale Marathi literary journals have supported this movement. According to the Encyclopaedic Dictionary of Marathi Literature, -The focus of these magazines is their insistence on locating contemporary Marathi poetry in the 


\section{GAP BODHI TARU -}

\section{An International Peer-Reviewed \\ Open Access Journal of Humanities}

context of the tremendous social changes that have taken place due to globalization and the policies of the Indian Government like liberalization and privatization

\section{ANCIENT HISTORICAL TRAIL}

Many religious movements occurred in India since ancient times. Buddhism, Jainism, Bhakti Movement have socioreligious characters. And most of these movements aim at the balanced and happy society and people who are devoid of any discrimination. And many of these movements had literature at its base with an ideological phenomenon. And many times they have emerged as the protest movements.

\section{RECENT PAST}

=Pained' by Una episode, many Dalits plan to embrace Buddhism.

Post Una incident 1,000 people from the community in Banaskantha district have so far expressed their desire to convert to Buddhism...' (https://indianexpress.com)

This news in the Indian Express on July 27, 2016, shows the utter importance of a well thought out discussion on the topics of Culture and Cultural studies with a very specific reference to the newly revised concept of religion and its role in providing social identity, so- called-security and perceived- justice.

Theory of Cultural Studies initiates intellectual inquiries into different socio-political and cultural forms and practices. It draws on various fields yet does not completely identify with any of those fields. So when talking about the dialogic nature of Buddhist ideology and the related Dalit practices in contemporary India, the cultural consumption of their everyday life can be discussed under various approaches of Cultural Studies.

Another important milestone in the history of Dalit emancipation was the mass conversion of Dalits into Buddhism in Maharashtra and UP. It was in response to the call given by Dr. Babasaheb Ambedkar to Leave the Exploitative Hindu religion. .He declared in Yeola conference (Nasik) in 1935 that he was born as a Hindu, but, he would not die as a Hindu. So he, together with his followers, converted to Buddhism in 1956 at Nagpur. This process of conversion has to be seen in the context of politics through which the Dalits were seeking assertion.' (https://countercurrents.org/2017/05/12/the-political-buddha-of-dalits-in-up)

\section{MULTIPLE NARRATIVES AND OUTCOMES OF THE EMANCIPATORY MOVEMENTS}

Conversion is a complex and delicate issue that has been obfuscated and vitiated when viewed in a communal and chauvinistic context. The 'Savarna' response to Dalit conversion as expressed in anti-conversion laws, under the guise of protecting the Dalits, traps them in a 'no entry, no exit' situation. We need a theoretical framework within a fourfold discourse, seeking to analyze conversion as 'dharmantar'. Each discourse considers the perspective of the converter and the converted, opening up in turn issues of civil rights (including that of Dalits) that must not be compromised. It is necessary to view Dalit- Buddhist equation as a 'process' rather than an event if one is to address the complexities involved. (https://countercurrents.org/2017/05/12/thepolitical-buddha-of-dalits-in-up)

As the cultural critics in England like Richard Hoggart, Raymond Williams, E.P. Thompson and Stuart Hall have challenged the classical, exclusivist and anti-democratic conception of culture and started a new area of Cultural Studies, in current India also certain socio-political issues like the Dalit- Buddhist equations in the light of new identity politics requires to be seen as multiple narratives outside the canonized academic world.

The current scenario is becoming very complex day by day. Ambedkar believed that the core idea of Buddhism is not based on any caste discrimination. As there is no propagation of any God, there is no base of any hierarchy.

\section{IMPORTANCE OF SOCIAL HISTORY AND CULTURAL CHANGES:}

1. It helps to follow a cultural trail on the basis of available literature and to establish a relationship between the socio-literary movements and the emancipation of Dalits.

2. One can develop insights into the process of re-emergence of Buddhism in the west and northern parts of India in the twentieth century under and after the Ambedkarite movement.

3. It helps to map the spread of emancipatory literary movements in India and generate a clear picture of the different caste groups and communities through essentialist and idealist lens

4. To look at the role of these movements in the everyday life of the Dalits and the literary-philosophical facets and how they give meaning and identity to the lives of these people.

5. We can analyze the philosophical trends and the main tenets practiced by the Buddhist Dalits of India along with the ritual practices. 


\section{GAP BODHI TARU -}

\section{An International Peer-Reviewed \\ Open Access Journal of Humanities}

\section{But the following questions still remain relevant:}

Is there a common thread of collective injustice in the emancipatory movements and how literature has played a pivotal role in success? Has the literature benefitted by supporting and being a vehicle of these emancipatory social movements? Is the new identity of Dalit- Buddhist equation working in favor of the socio-political balance of Dalits? Has Ambedkar provided a way out of the Casteist discrimination by Annihilation of the Caste'? Has the Brahminical hegemony been affected by the neo-Buddhist rise in the socio-political arena?

As Quoted in =The Atlantic', -Over 10 Dalit families got converted to Buddhism after the mass caste violence in Saharanpur district, UP in 2017. Bhim Army, a new group that seeks to give Dalit politics a more aggressive form to Dalit politics says that it is considering a mass exercise to convert to Buddhism. Last year over 3-Dalits got converted in Gujarat after seven of their caste got flogged for skinning a dead cow $\|$

( https://www.theatlantic.com/international/.../04/dalit-buddhism-conversion.../557570.

An assessment of liberal democracy from the point of view of the Dalit would be quite inadequate if it were done solely on the basis of the structural aspects of inequality and Liberal Democracy in India and the Dalit Critique. For a more comprehensive assessment of liberal democracy, it is necessary to bring into central focus the discussion of the language of self-esteem and self-respect, which seems to have escaped the attention of scholars of Indian democracy. The news report by Manu Mudgal in Indiaspeak says, -Today, around $87 \%$ of Buddhists in India are neo-converts; the rest belong to traditional Buddhist communities, mostly in the north-east of India and other Himalayan regions. However, a Dalit audit of liberal democracy over the past 60 years suggests that liberal democracy has proffered a skewed response to the Dalit question, one hinging on everyday forms of humiliation, degradation, and repulsion. Among the non-Dalits, self-esteem evokes at best continuous and humiliating taunting directed at Dalits-for example, Dalits are referred to as sarkar ke jawai (free rider)-and at worst, it leads the upper caste to violent reactions against Dalits' own pursuit for self-esteem. There are crude as well as cunning methods that the adversaries of the Dalit deploy with the intention to deny the latter a sense of selfesteem and self-respect, with the effect of reducing the Dalit to a squalor that has been described as a "hellhole.|| (http://www.indiaspend.com/cover-story/dalits-are-still-converting-to-buddhism-but-at-a- dwindling-rate34369)

The liveliness and authenticity of their expressions are captured all across their writings. Shame, anger, sorrow and indomitable hope are the trademarks of this marginalized people and literature created by them. As the world moves toward becoming a global village, some past experiences and lessons learned become precious and crucial to understanding the common sense and sensibilities.

\section{REFERENCES}

"RPI's Quest for Relevance." Economic and Political Weekly30, no. 49 (1995): 3113-114.

(https://countercurrents.org/2017/05/12/the-political-buddha-of-dalits-in-up)

(https://indianexpress.com)

Bhoite, Uttam, and Anuradha Bhoite. "The Dalit Sahitya Movement In Maharashtra: A Sociological Analysis." Sociological Bulletin 26, no. 1 (1977): 60-75.

Chandramauli, C. "Census of India 2011: provisional population totals paper 1 of 2011 India Series 1, Chapter 6." New Delhi, India: Office of the Registrar General \& Census Commissioner (2011).

Constable, Philip. "Early Dalit Literature and Culture in Late Nineteenth- and Early Twentieth-Century Western India." Modern Asian Studies 31, no. 2 (1997): 317-38.

Contursi, Janet A. "Militant Hindus and Buddhist Dalits: Hegemony and Resistance in an Indian Slum." American Ethnologist 16, no. 3 (1989): 441-57.

Deshpande, J. V. "Behind Dalit Anger." Economic and Political Weekly 32, no. 33/34 (1997): 2090-091

Ghose, Sagarika. -The Dalit in India.|| Social Research, vol. 70, no. 1, 2003

Ghosh G.K., Ghosh Shukla, =Dalit Women', A.P.H. Publishing Corporation, New Delhi, 1997.

Gnaniah D., = Obamas of America and Dalits of India- Saga of two Black people', New Delhi, Pragun Publication, 2011.

Gopal Guru, and V. Geetha. New Phase of Dalit-Bahujan Intellectual Activity." Economic and Political Weekly 35, no. 3 (2000): 130-34

http://www.indiaspend.com/cover-story/dalits-are-still-converting-to-buddhism-but- at-a-dwindling-rate-34369

https://www.theatlantic.com/international/.../04/dalit-buddhism-conversion.../557570

Jadhav Narendra, =Outcaste: A Memoir', New Delhi: Viking Penguin, 2003 Jammanna Akepogu, Pasala Sudhakar, Dalits'

Struggle for Social Justice in Andhra Pradesh (1956-2008): Cambridge Scholars Publishing, 14-Dec-2016

Jogdand P.G., _Dalit Women, Issues and Perspectives', Gyan Publishing House, New Delhi.1995 


\section{GAP BODHI TARU - An International Peer-Reviewed \\ Open Access Journal of Humanities}

Jogdand, P. G. "Dalits in Maharashtra: Challenges Ahead." Economic and Political Weekly 32, no. 51 (1997): 3249250.

Omvedt, Gail. Buddhism in India: Challenging Brahmanism and Caste, 3rd ed. London/New Delhi/Thousand Oaks: Sage, 2003.

Omvedt, Gail. Dalits and the democratic revolution: Dr. Ambedkar and the Dalit movement in Colonial India. SAGE Publications India, 1994.

Paik, Shailaja. -Amchya Jalmachi Chittarkatha (The Bioscope of Our Lives): Who Is My Ally?\| Economic and Political Weekly, vol. 44, no. 40, 2009

Singh Rajkumar, Encyclopaedia of Marathi Literature , Anmol Publications, 2009

Still, Clarinda. -The Journal of the Royal Anthropological Institute.|| The Journal of the Royal Anthropological Institute, vol. 16, no. 2, 2010

Taylor, Steve. "Religious Conversion and Dalit Assertion among a Punjabi Dalit Diaspora." Sociological Bulletin 63, no. 2 .

Verma, Vidhu. "Reinterpreting Buddhism: Ambedkar on the Politics of Social Action." Economic and Political Weekly 45, no. 49 (2010): 56-65.

Vivek Kumar. -Understanding Dalit Diaspora.|| Economic and Political Weekly, vol. 39, no. 1, 2004.

Wankhede, Harish S. -The Political and the Social in the Dalit Movement Today.\| Economic and Political Weekly, vol. 43, no. 6, 2008

Webster John; = The Dalit Situation in India Today', International Journal of Frontier Missions 18:1 Spring 2001

Webster, John C. B. "Understanding The Modern Dalit Movement." Sociological Bulletin 45, no. 2 (1996): $189-204$. 